\title{
ANALYSIS AND ASSESSMENT OF WATER TREATMENT PLANT RELIABILITY
}

\section{ANALIZA I OCENA NIEZAWODNOŚCI STACJI UZDATNIANIA WODY}

\author{
Dawid Szpak, Barbara Tchórzewska - Cieślak \\ Politechnika Rzeszowska im. Ignacego Łukasiewicza
}

\begin{abstract}
The subject of the publication is the analysis and assessment of the reliability of the surface water treatment plant (WTP). In the study the one parameter method of reliability assessment was used. Based on the flow sheet derived from the water company the reliability scheme of the analysed WTP was prepared. On the basis of the daily WTP work report the availability index $K_{g}$ for the individual elements included in the WTP, was determined. Then, based on the developed reliability scheme showing the interrelationships between elements, the availability index $K_{g}$ for the whole WTP was determined. The obtained value of the availability index $K_{g}$ was compared with the criteria values.
\end{abstract}

Keywords: reliability, the availability index, water treatment plant

Streszczenie: Tematem publikacji jest analiza oraz ocena niezawodności stacji uzdatniania wody (SUW) powierzchniowej. $W$ pracy wykorzystano metode jednoparametrycznq oceny niezawodności. W oparciu o schemat technologiczny uzyskany od przedsiębiorstwa wodociagowego sporządzono schemat niezawodnościowy analizowanego SUW. Na podstawie dobowego raportu pracy SUW, wyznaczono wskaźnik gotowości $K_{g}$ dla poszczególnych elementów wchodzacych $w$ sklad SUW. Nastepnie na podstawie opracowanego schematu niezawodnościowego wyznaczono wskaźnik gotowości $K_{g}$ dla catego SUW. Otrzymana wartość wskaźnika gotowości $K_{g}$ porównano $z$ wartościami kryterialnymi.

Stowa kluczowe: niezawodność, wskaźnik gotowości, stacja uzdatniania wody 
Analysis and assessment of water treatment plant reliability

Analiza i ocena niezawodności stacji uzdatniania wody

\section{ANALYSIS AND ASSESSMENT OF WATER TREATMENT PLANT RELIABILITY}

\section{Introduction}

In the face of advancing climate change, especially the ever more frequent natural disasters such as floods and droughts, the key to ensure a continuous supply of water to consumers is to keep the water supply subsystem, including the water treatment plant (WTP), in a state of availability. By this is meant carrying out processes for water treatment quality in accordance with Regulation [7], in a continuous manner, so that it was possible to cover the current demand for water for the city. Reliable operation of the WTP can meet the requirements for water supply companies contained in the Act [16]. Ineffective treatment process may result in biological or chemical contamination of drinking water, which is a serious threat to lives and health of water consumers $[1,3,11,15]$. In terms of ensuring an adequate level of water consumers protection it is important to systematically make preventive renovations, influencing the reduction of the probability of making emergency renovations [8]. Growing requirements for the safety of water consumers induced many authors to attempt to develop a methodology for risk analysis in technical systems $[4,12,14]$.

The collective water supply system (CWSS) is part of the critical infrastructure, which, according to the Act [17], is crucial for the security of the state and citizens. Water supply subsystem is an integral part of the CWSS, therefore it should be protected as results directly from above mentioned Act. Protection of critical infrastructure is defined as [17]:

"(...) all actions aimed at ensuring the functionality, continuity and integrity of critical infrastructures in order to prevent threats, risks or weaknesses and limitations and neutralize their effects and the rapid restoration of infrastructure in the event of failure, attacks and other events interfere with its proper functioning."

The control of the Supreme Audit Office (Polish abbreviation NIK) of selected entities responsible for the protection of objects of critical infrastructure in Poland, at the government, provincial, district and municipal level, carried out from 2015 to 2016 , revealed a number of irregularities in the protection of those objects. The main allegations of the NIK were, among others, lack of physical protection of objects of critical infrastructure, lack of monitoring, lack of developed solutions in case of sabotage, lack of proper security gates, security systems, lack of cooperation between the relevant bodies responsible for the protection. In relation to the WTP, the NIK drew attention mainly to the inadequate protection of object from intrusion by unauthorized individuals and hence the ability to easily poison water intended for consumption by thousands of citizens.

The main aim of this work is the analysis and assessment of the WTP reliability. In addition, the study attempts to assess level of security of the WTP as part of the 
CWSS which is part of the critical infrastructure of the state. The analysis was conducted on the example of the WTP in a district town in south-eastern Poland.

\section{Materials and methods}

\section{Characteristics of the basic indicators used in assessing the CWSS reliability}

Quantitatively, the reliability of the systems is described using for this purpose the so-called reliability measures. Key indicators used in the analysis of the CWSS reliability are described in the following paragraphs $[2,5,6,13]$.

The average time of failure-free operation $T_{p}$ is the expected value of the random variable $T_{p}$, specifying time of operation (availability) of the system (or its components) between two successive failures [5, 13]:

$$
\mathrm{T}_{\mathrm{p}}=\frac{1}{\mathrm{k}+\mathrm{z}} \cdot\left(\sum_{\mathrm{i}=1}^{\mathrm{k}} \mathrm{t}_{\mathrm{pi}}+\mathrm{z} \cdot \mathrm{t}\right)
$$

where:

$t$ - the time of observation,

$t_{p i}$ - the i-th operation time of objects that can be damaged,

$\mathrm{k}$ - the number of periods of operation of objects that can be damaged,

$\mathrm{z}$ - the number of periods of operation of objects that cannot be damaged.

The average repair time $T_{n}$ is understood as the expected value of time from the moment of failure appearance until the moment when the element is again included in operation $[5,13]$ :

where:

$$
\mathrm{T}_{\mathrm{n}}=\mathrm{T}_{\mathrm{d}}+\mathrm{T}_{0}
$$

$\mathrm{T}_{\mathrm{d}}$ - time of waiting for repair $[\mathrm{h}]$

$\mathrm{T}_{0}$ - time of real repair $[\mathrm{h}]$.

The average repair time can be determined based on the operating data $[5,13]$ :

$$
T_{n}=\frac{1}{n_{o}} \sum_{i=1}^{n_{o}} t_{n i}
$$

where:

$\mathrm{n}_{\mathrm{o}} \quad$ - the number of repairs in the considered period,

$t_{n i} \quad-$ the duration of the $\mathrm{i}$-th repair.

The availability index $\mathrm{K}_{\mathrm{g}}(\mathrm{t})$ determines the probability of the efficiency of the object or system at a given time $t[5,13]$ :

$$
K_{g}=\frac{T_{p}}{T_{p}+T_{n}}
$$


Analysis and assessment of water treatment plant reliability Analiza i ocena niezawodności stacji uzdatniania wody

The standstill index (unreliability) $\mathrm{K}_{\mathrm{p}}$ determines the probability of failure of an object or system at a given time $\mathrm{t}[5,13]$ :

$$
K_{p}=1-K_{g}
$$

The study used a one parameter method of reliability assessment presented in the works, among others, $[5,6,13]$. The availability index $\mathrm{K}_{\mathrm{g}}$ for the whole WTP was determined based on the values of this index for the individual components of the WTP.

\section{Characteristics of reliability structures}

In the reliability analysis of technical systems the following reliability structures are distinguished $[5,6]$.

- Serial structure - used if damage of any element causes damage of the whole subsystem.

The availability index $\mathrm{K}_{\mathrm{g}}$ for the serial structure is equal to the product of the reliability of its individual components:

$$
K_{g}=\prod_{i=1}^{n} K_{i}
$$

where:

$\mathrm{i}=1,2,3, \ldots, \mathrm{n} ., \mathrm{n}$-number of elements

- Threshold structure - used if a failure of subsystem occurs at the moment of failure " $k$ " from among all the "M" elements.

The availability index $\mathrm{K}_{\mathrm{g}}$ for the homogeneous threshold structure is determined from the formula:

$$
K_{g}=\sum_{k=0}^{k_{\text {dop }}}\left(\begin{array}{c}
M \\
k
\end{array}\right) \cdot K_{g 0}{ }^{M-k} \cdot K_{p 0}{ }^{k}
$$

where:

$\mathrm{k}$ - the number of damaged elements,

$\mathrm{k}_{\mathrm{dop}}$ - permissible number of damaged elements,

$\mathrm{K}_{\mathrm{g} 0}$ - the availability index of a single element,

$\mathrm{K}_{\mathrm{p} 0}$ - the standstill index of a single element,

M - the number of all elements. 
- Parallel structure - used if a failure of subsystem occurs when all homogeneous components are damaged.

The availability index $\mathrm{K}_{\mathrm{g}}$ for the parallel structure is determined from the formula:

$$
K_{g}=1-\prod_{j=1}^{M}\left(1-K_{g 0}\right)
$$

where:

$\mathrm{K}_{\mathrm{g} 0}$ - the availability index of a single element,

M - the number of all elements.

\section{Case Study}

\section{Characteristics of the analysed WTP}

The district town with around 37000 inhabitants and covering an area of 36.52 $\mathrm{km}^{2}$ was analysed. The collective water supply system in the analysed town is supplied with water by two water intakes:

- boundary with a capacity of $17280 \mathrm{~m}^{3} / \mathrm{d}$

- underground with a capacity of $348 \mathrm{~m}^{3} / \mathrm{d}$.

Due to the small capacity of the underground water intake only the WTP for surface water was analysed. Water from the intake is treated in the WTP based on Actiflo system and a set of nine rapid filters. Treated water after adding chlorine goes to the two-chamber clean water tank with a capacity of $5000 \mathrm{~m}^{3}$. This tank, if the excessive turbidity in the raw water is found or a crisis situation occurs, can supply water for about 22 hours. The clean water tanks also provide the necessary time for water to contact with chlorine. Water is pumped to the network by four pumps III $^{\circ}$ controlled by an algorithm of constant discharge pressure by means of a frequency converter. During normal operation one pump is working for 24 hours and is replaced by the other one. Irregularity of the daily water consumption is compensated by the two-chamber network tank with a capacity of $1,800 \mathrm{~m}^{3}$. The water supply system of the analysed city is mixed, ring - branched [9]. The analysed WTP has the system for protecting consumers from consuming contaminated water, consisting of a number of protective barriers [10].

On the basis of the WTP technological diagram provided by the water company, being in operation since the modernization completed in 2009 , the reliability scheme for the analysed WTP, was made (Figure 1). 


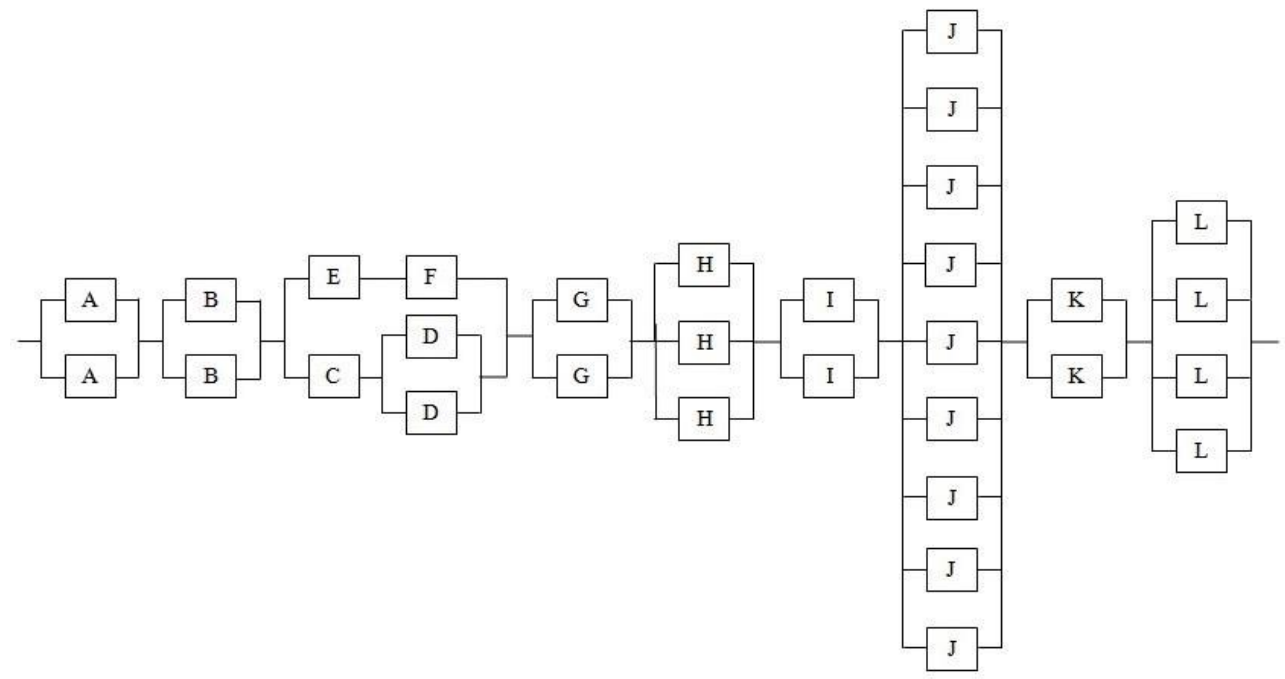

Fig.1. The reliability scheme for the analysed WTP

Abbreviations used in Figure 1: A - inlet port, B - grit chamber, C - collective well, $\mathrm{D}$ - pump $\mathrm{I}^{\mathrm{o}}, \mathrm{E}$ - collective well (reserve), F - pump $\mathrm{I}^{\mathrm{o}}$ (reserve), G - primary settling tank, $\mathrm{H}$ - pump $\mathrm{II}^{\mathrm{O}}$, I - block Actiflo, J - rapid filter, $\mathrm{K}$ - clean water tank, L - pump III ${ }^{\mathrm{O}}$.

\section{Results}

On the basis of the operating data (daily report of the WTP operation) and based on the formulas (1) - (4) the availability index $\mathrm{K}_{\mathrm{g}}$ for each object of the WTP was calculated, as shown in Table 1. All reported failures in the WTP in $2010-2015$ (the period after the WTP modernization), were analysed.

Table 1. The availability index for the objects included in the analysed WTP

\begin{tabular}{|l|c|}
\hline \multicolumn{1}{|c|}{ Object } & The availability index $\mathrm{K}_{\mathrm{g}}$ \\
\hline Inlet port & $\mathrm{K}_{\mathrm{gA}}=0,9980$ \\
\hline Grit chamber & $\mathrm{K}_{\mathrm{gB}}=0,9991$ \\
\hline Collective well & $\mathrm{K}_{\mathrm{gC}}=0,9999$ \\
\hline Pump I $^{\mathrm{O}}$ & $\mathrm{K}_{\mathrm{gD}}=0,9896$ \\
\hline Collective well (reserve) $^{\mathrm{g}}$ & $\mathrm{K}_{\mathrm{gE}}=0,9999$ \\
\hline Pump I ${ }^{\mathrm{O}}$ (reserve) & $\mathrm{K}_{\mathrm{gg}}=0,9896$ \\
\hline Primary settling tank & $\mathrm{K}_{\mathrm{gG}}=0,9998$ \\
\hline Pump II & $\mathrm{K}_{\mathrm{gH}}{ }^{\mathrm{O}}=0,9894$ \\
\hline Actiflo block & $\mathrm{K}_{\mathrm{gI}}=0,9731$ \\
\hline Rapid filtr & $\mathrm{K}_{\mathrm{gg}}=0,9972$ \\
\hline Clean water tank & $\mathrm{K}_{\mathrm{gK}}=0,9973$ \\
\hline Pump III & $\mathrm{K}_{\mathrm{gL}}=0,9842$ \\
\hline
\end{tabular}


On the basis of the developed reliability scheme, showing the interrelationship between elements (Figure 1), and based on the formulas (6) - (8), the availability index $\mathrm{K}_{\mathrm{g}}$ for the individual structures and for the whole WTP, was determined.

$$
\begin{array}{ll}
K_{g I}=1-\left(1-K_{g A}\right)^{2}=0,9999 & K_{g V I}=1-\left(1-K_{g I V}\right)\left(1-K_{g V}\right)=0,9999 \\
K_{g I I}=1-\left(1-K_{g B}\right)^{2}=0,9999 & K_{g V I I}=1-\left(1-K_{g G}\right)^{2}=0,9999 \\
K_{g I I I}=1-\left(1-K_{g D}\right)^{2}=0,9999 & K_{g V I I I}=1-\left(1-K_{g H}\right)^{3}=0,9999 \\
K_{g I V}=K_{g C} \cdot K_{g I I I}=0,9998 & K_{g I X}=1-\left(1-K_{g I}\right)^{2}=0,9993 \\
K_{g V}=K_{g E} \cdot K_{g F}=0,9895 & \\
K_{g X}=\left(\begin{array}{l}
9 \\
0
\end{array}\right) \cdot K_{g J}{ }^{9} \cdot K_{p J}{ }^{0}+\left(\begin{array}{l}
9 \\
1
\end{array}\right) \cdot K_{g J}{ }^{9-1} \cdot K_{p J}{ }^{1}+\left(\begin{array}{l}
9 \\
2
\end{array}\right) \cdot K_{g J}{ }^{9-2} \cdot K_{p J}{ }^{2}=0,9999 \\
K_{g X I}=1-\left(1-K_{g K}\right)^{2}=0,9999 \\
K_{g X I I}=1-\left(1-K_{g L}\right)^{4}=0,9999 \\
K_{g S U W}=K_{g I} \cdot K_{g I I} \cdot K_{g V I} \cdot K_{g V I I} \cdot K_{g V I I I} \cdot K_{g I X} \cdot K_{g X} \cdot K_{g X I} \cdot K_{g X I I}=0,9985
\end{array}
$$

The calculations were performed for the real demand for water, not for the total production capacity of the WTP, which is much greater than the demand for water for the city. The obtained value of the availability index $\mathrm{K}_{\mathrm{gsuw}}$ was compared with the criteria values presented in [18]. The collective water supply system in the analysed city supplies water to about 34500 inhabitants and covers $100 \%$ of water demand for the city. The value of the required availability index for the analysed CWSS is $\mathrm{K}_{\mathrm{gSZZW}}=0.9150137$. Since the CWSS consists of two subsystems, the value of the availability index for each of them is $K_{\text {gwym }}=\sqrt{0,9150137}=0,9566$. Comparing the obtained availability index with the required value it was stated that $\mathrm{K}_{\mathrm{gsuw}}>\mathrm{K}_{\mathrm{gwym}}$.

\section{Conclusions}

The WTP reliability analysis of the analysed city was carried out on the basis of the operating data provided by the water company. The water treatment plant of the analysed city meets the reliability requirements for this type of objects. Due to the significant reserve of objects included in the WTP the probability of the WTP insufficiency is insignificant.

Special attention is drawn by a high level of reserve water in the clean water tanks $\mathrm{V}=5000 \mathrm{~m}^{3}$ and in the network tanks $\mathrm{V}=1800 \mathrm{~m}^{3}$. In case of the WTP insufficiency those tanks can be a source of water for the city, which additionally increases the level of water consumers protection.

The water treatment plant of the analysed city has a comprehensive protection system: the protection zones of water intake, the high fence of the WTP, the automatic gate operated by the WTP employees, full monitoring of the WTP, automation of treatment processes, continuous supervision made by employees over the WTP operation (SCADA system), parallel automatic and manual monitoring of water quality, as well as an emergency response plan in case of a crisis situation. 
Analysis and assessment of water treatment plant reliability Analiza i ocena niezawodności stacji uzdatniania wody

Therefore the protection of the analysed WTP of the analysed city meets the requirements for critical infrastructure .

\section{Literature}

[1] Boryczko K., Tchórzewska-Cieślak B.: Analysis of risk of failure in water main pipe network and of developing poor quality water. Environment Protection Engineering, 40(4)/2014, s. 77-92.

[2] Budziło B., Polok-Kowalska A.: Dwuparametryczna ocena niezawodności funkcjonowania podsystemu dostawy wody dla miasta Limanowa. Czasopismo Techniczne. Środowisko. R. 104, z. 2-Ś/2007, s. 29-38.

[3] Hrudey S.E., Hrudey E.J., Pollard S.J.: Risk management for assuring safe drinking water. Environment International, 32(8)/ 2006, s. 948-957.

[4] Iacob, I.E., Apostolou, A.: A quantitative risk analysis framework for bow-tie models. Proceedings of the 2015 7th International Conference on Electronics, Computers and Artificial Intelligence, ECAI 2015, 7301176, pp. Y43-Y46.

[5] Kwietniewski M., Roman M., Kłoss-Trębaczkiewicz H.: Niezawodność wodociągów i kanalizacji. Arkady, Warszawa, 1993.

[6] Rak J.: Niezawodność systemu uzdatniania wód powierzchniowych. Zeszyty Naukowe Politechniki Rzeszowskiej, nr 20, Rzeszów, 1993.

[7] Rozporządzenie Ministra Zdrowia z dnia 13 listopada 2015 r. w sprawie jakości wody przeznaczonej do spożycia przez ludzi (Dz.U. 2015 poz. 1989).

[8] Studziński A., Pietrucha-Urbanik K.: Preventive maintenance and reliability of water supply system elements. Czasopismo Inżynierii Lądowej, Środowiska i Architektury, JCEEA, t. XXXII, z. 62 (3/I/15), lipiec-wrzesień 2015, s. 429-436. (DOI: 10.7862/rb.2015.126).

[9] Szpak D., Tchórzewska - Cieślak B.: Analiza awaryjności sieci wodociągowej $\mathrm{w}$ aspekcie bezpieczeństwa funkcjonowania infrastruktury krytycznej. CHEMIK, 68(10)/2014, s. 862-867.

[10] Szpak D., Tchórzewska - Cieślak B.: Analiza i ocena zabezpieczenia systemów zbiorowego zaopatrzenia $\mathrm{w}$ wodę przed incydentalnym skażeniem. Journal of KONBiN 2(34)/2015, s. 49 - 58 (DOI 10.1515/jok-2015-023).

[11] Szymik-Gralewska J., Zimoch I.: Zasady optymalizacji niezawodności eksploatacji stacji uzdatniania wody, Monografia - XXIII Międzynarodowa Konferencja Naukowo - Techniczna „Zaopatrzenie w wodę, jakość i ochrona wód- WODA 2014", s. 157-178.

[12] Tchórzewska-Cieślak B.: Method of assessing of risk of failure in water supply system. European safety and reliability conference 2007 (ESREL 2007), Risk, reliability and societal safety, Taylor \& Francis, 2, 1535-1539. 
[13] Tchórzewska-Cieślak B.: Niezawodność i bezpieczeństwo systemów komunalnych na przykładzie systemu zaopatrzenia w wodę. Oficyna Wydawnicza Politechniki Rzeszowskiej, Rzeszów, 2008.

[14] Tchórzewska-Cieślak B., Boryczko K., Piegdoń I.: Possibilistic risk analysis of failure in water supply network. Safety and Reliability: Methodology and Applications - Proceedings of the European Safety and Reliability Conference, ESREL 2014, pp. 1473-1480.

[15] Tchórzewska-Cieślak B., Pietrucha-Urbanik K., Szpak D.: Safety problems of small water supply systems. Journal of KONBiN 1(37)/2016, pp. 51-72 (DOI 10.1515/jok-2016-0003).

[16] Ustawa $\mathrm{z}$ dnia 7 czerwca 2001 r. o zbiorowym zaopatrzeniu w wodę i zbiorowym odprowadzaniu ścieków (Dz.U. $2001 \mathrm{nr} 72$ poz. 747) z późniejszymi zmianami.

[17] Ustawa z dnia 26 kwietnia 2007 r. o zarządzaniu kryzysowym (Dz.U. 2007 $\mathrm{Nr} 89$ poz. 590) z późniejszymi zmianami.

[18] Wieczysty A.: Metody oceny i podnoszenia niezawodności działania komunalnych systemów zaopatrzenia w wodę. Monografie Komitetu Inżynierii Środowiska Polskiej Akademii Nauk, vol. 2., Komitet Inżynierii Środowiska PAN, Kraków, 2001.

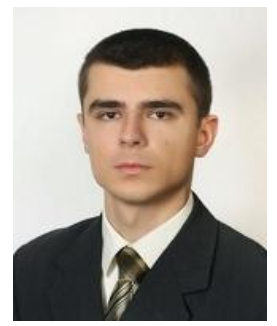

Dawid Szpak, Msc.Eng. is working in the post of an assistant in Rzeszow University of Technology, Faculty of Civil, Environmental Engineering and Architecture, Department of Water Supply and Sewage Systems. Research interests: reliability and security of water supply systems, incidental events in water supply systems (Share 50\%).

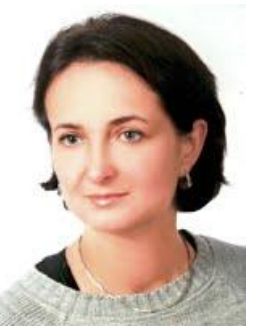

Prof. Barbara Tchórzewska-Cieslak, Ph.D.Eng. is working in the post of an associate professor in Rzeszow University of Technology, Faculty of Civil, Environmental Engineering and Architecture, Department of Water Supply and Sewage Systems. Research interests: water supply systems, reliability and safety of engineering systems, unconventional methods of risk analysis and assessment (Share 50\%). 
Analysis and assessment of water treatment plant reliability

Analiza i ocena niezawodności stacji uzdatniania wody

\section{ANALIZA I OCENA NIEZAWODNOŚCI STACJI UZDATNIANIA WODY}

\section{Wstęp}

W obliczu postępujących zmian klimatycznych, szczególnie coraz częściej występujących klęsk żywiołowych jak powodzie oraz susze, kluczowym dla zapewnienia ciągłości dostawy wody do konsumentów jest utrzymanie podsystemu dostawy wody, w tym stacji uzdatniania wody (SUW) w stanie zdatności. Rozumie się przez to prowadzenie procesów mających na celu uzdatnienie wody do jakości zgodnej z Rozporządzeniem [7] w sposób ciągły, tak aby możliwe było pokrycie aktualnego zapotrzebowania na wodę dla miasta. Niezawodne funkcjonowanie SUW, umożliwia spełnienie wymagań stawianych przedsiębiorstwom wodociągowym zawartych w Ustawie [16]. Nieskuteczny proces uzdatniania może skutkować biologicznym lub chemicznym zanieczyszczeniem wody przeznaczonej do spożycia, co stanowi poważne zagrożenie dla życia i zdrowia konsumentów wody $[1,3,11,15]$. W zakresie zapewnienia odpowiedniego poziomu bezpieczeństwa konsumentów wody, istotne znaczenie ma systematyczne prowadzenie odnów profilaktycznych, wpływających na obniżenie prawdopodobieństwa wykonywania odnów awaryjnych [8]. Rosnące wymagania dotyczące bezpieczeństwa konsumentów wody skłoniły wielu autorów do podjęcia próby opracowania metodyki dla analizy ryzyka w systemach technicznych $[4,12,14]$. System zbiorowego zaopatrzenia w wodę (SZZW) wchodzi w skład infrastruktury krytycznej, czyli zgodnie z Ustawą [17] jest systemem kluczowym dla bezpieczeństwa państwa oraz obywateli. Podsystem dostawy wody stanowiący integralną część SZZW, powinien być więc być objęty ochroną wynikającą wprost z ww. Ustawy. Przez ochronę infrastruktury krytycznej rozumie się [17]:

“(...) wszelkie działania zmierzające do zapewnienia funkcjonalności, ciagłości działań $i$ integralności infrastruktury krytycznej $w$ celu zapobiegania zagrożeniom, ryzykom lub słabym punktom oraz ograniczenia i neutralizacji ich skutków oraz szybkiego odtworzenia tej infrastruktury na wypadek awarii, ataków oraz innych zdarzeń zaktócajacych jej prawidłowe funkcjonowanie;"

Kontrola Najwyższej Izby Kontroli (NIK) dotycząca wybranych podmiotów odpowiedzialnych za ochronę obiektów infrastruktury krytycznej w Polsce, zarówno na szczeblu rządowym, wojewódzkim, powiatowym jak i gminnym, przeprowadzona w latach 2015 - 2016, wykazała szereg nieprawidłowości w ochronie tych systemów. Do głównych zarzutów NIK należały m.in. brak fizycznej ochrony obiektów infrastruktury krytycznej, brak monitoringu, brak opracowanych rozwiązań na wypadek wystąpienia sabotażu, brak właściwego zabezpieczenia bram wjazdowych, brak zabezpieczenia systemów sterowania oraz brak współpracy pomiędzy odpowiednimi podmiotami odpowiedzialnymi za ich ochronę. 
W odniesieniu do SUW, NIK zwróciła uwagę przede wszystkim na niewłaściwe zabezpieczenie obiektu przed wtargnięciem osób niepożądanych, a co za tym idzie możliwość łatwego zatrucia wody przeznaczonej do spożycia przez tysiące obywateli.

Głównym celem pracy jest analiza oraz ocena niezawodności SUW. Ponadto, w pracy podjęto próbę oceny stopnia ochrony SUW, jako elementu SZZW stanowiącego element infrastruktury krytycznej państwa. Analizę przeprowadzono na przykładzie SUW miasta powiatowego zlokalizowanego $\mathrm{W}$ południowowschodniej Polsce.

\section{Materiały i metody}

Charakterystyka podstawowych wskaźników wykorzystywanych w ocenie niezawodności SZZW

Ilościowo niezawodność systemów opisuje się, wykorzystując do tego celu tzw. miary niezawodności. Podstawowe wskaźniki stosowane $\mathrm{w}$ analizie niezawodności SZZW zostały opisane w kolejnych akapitach $[2,5,6,13]$.

Średni czas pracy bezuszkodzeniowej $\mathrm{T}_{\mathrm{p}}$ jest to wartość oczekiwana zmiennej losowej $\mathrm{T}_{\mathrm{p}}$, określającej czas pracy (zdatności) systemu (lub jego elementów), między dwoma kolejnymi uszkodzeniami $[5,13]$ :

$$
\mathrm{T}_{\mathrm{p}}=\frac{1}{\mathrm{k}+\mathrm{z}} \cdot\left(\sum_{\mathrm{i}=1}^{\mathrm{k}} \mathrm{t}_{\mathrm{pi}}+\mathrm{z} \cdot \mathrm{t}\right)
$$

gdzie:

$\mathrm{t}$ - czas obserwacji,

$t_{\mathrm{pi}}$ - wartość i-tego czasu pracy obiektów uszkadzających się,

k - liczba okresów pracy obiektów uszkadzających się,

z - liczba okresów pracy obiektów nieuszkadzających się,

Średni czas naprawy $T_{n}$ jest rozumiany jako wartość oczekiwana czasu liczonego od chwili wystąpienia uszkodzenia, aż do momentu włączenia elementu do eksploatacji $[5,13]$ :

gdzie:

$$
\mathrm{T}_{\mathrm{n}}=\mathrm{T}_{\mathrm{d}}+\mathrm{T}_{0}
$$

$\mathrm{T}_{\mathrm{d}}$ - czas oczekiwania na naprawę $[\mathrm{h}]$,

$\mathrm{T}_{0}$ - czas naprawy rzeczywistej [h].

Średni czas naprawy można wyznaczyć w oparciu o dane eksploatacyjne [5, 13]:

$$
T_{n}=\frac{1}{n_{o}} \sum_{i=1}^{n_{o}} t_{n i}
$$

gdzie:

$\mathrm{n}_{\mathrm{o}}$ - liczba napraw w badanym okresie,

$t_{n i}$ - czas trwania i-tej naprawy. 
Analysis and assessment of water treatment plant reliability Analiza i ocena niezawodności stacji uzdatniania wody

Wskaźnik gotowości $\mathrm{K}_{\mathrm{g}}(\mathrm{t})$ określa prawdopodobieństwo sprawności obiektu lub systemu w danym czasie $\mathrm{t}[5,13]$ :

$$
K_{g}=\frac{T_{p}}{T_{p}+T_{n}}
$$

Wskaźnik postoju (zawodności) $\mathrm{K}_{\mathrm{p}}$ określa prawdopodobieństwo niesprawności obiektu lub systemu w danym czasie $\mathrm{t}[5,13]$ :

$$
K_{p}=1-K_{g}
$$

W pracy wykorzystano metodę jednoparametryczną oceny niezawodności przedstawioną w pracach m.in. $[5,6,13]$. Wskaźnik gotowości $\mathrm{K}_{\mathrm{g}}$ dla całego SUW wyznaczono na podstawie wartości tego wskaźnika dla pojedynczych elementów SUW.

\section{Charakterystyka struktur niezawodnościowych}

W analizie niezawodności systemów technicznych wyróżnia się następujące struktury niezawodnościowe $[5,6]$ :

- Struktura szeregowa - stosowana jeżeli uszkodzenie dowolnego elementu powoduje uszkodzenie całego podsystemu.

Wskaźnik gotowości $\mathrm{K}_{\mathrm{g}}$ dla struktury szeregowej, jest równy iloczynowi niezawodności poszczególnych jej elementów składowych:

$$
K_{g}=\prod_{i=1}^{n} K_{i}
$$

gdzie:

$\mathrm{i}=1,2,3, \ldots, \mathrm{n} ., \mathrm{n}-$ liczba elementów.

- Struktura progowa - stosowana jeżeli uszkodzenie podsystemu następuje $\mathrm{z}$ chwilą uszkodzenia „k” z pośród „M” wszystkich elementów.

Wskaźnik gotowości $\mathrm{K}_{\mathrm{g}}$ dla jednorodnej struktury progowej wyznacza się ze wzoru:

$$
K_{g}=\sum_{k=0}^{k_{d o p}}\left(\begin{array}{c}
M \\
k
\end{array}\right) \cdot K_{g 0}{ }^{M-k} \cdot K_{p 0}^{k}
$$

gdzie:

$\mathrm{k} \quad$ - liczba elementów uszkodzonych,

$\mathrm{k}_{\mathrm{dop}}$ - dopuszczalna liczba elementów uszkodzonych,

$\mathrm{K}_{\mathrm{g} 0}$ - wskaźnik gotowości pojedynczego elementu,

$\mathrm{K}_{\mathrm{p} 0} \quad$ - wskaźnik postoju pojedynczego elementu,

M - liczba wszystkich elementów. 
- Struktura równolegla - stosowana jeżeli uszkodzenie podsystemu następuje z chwilą uszkodzenia wszystkich jednorodnych elementów.

Wskaźnik gotowości $\mathrm{K}_{\mathrm{g}}$ dla struktury równoległej wyznacza się ze wzoru:

$$
K_{g}=1-\prod_{j=1}^{M}\left(1-K_{g 0}\right)
$$

gdzie:

$\mathrm{K}_{\mathrm{g} 0}$ - wskaźnik gotowości pojedynczego elementu,

M - liczba wszystkich elementów.

\section{Studium przypadku}

\section{Charakterystyka analizowanego SUW}

Analizie poddano miasto powiatowe liczące około 37000 mieszkańców i zajmujące powierzchnię $36,52 \mathrm{~km}^{2}$.

System zbiorowego zaopatrzenia $\mathrm{w}$ wodę analizowanego miasta jest zasilany w wodę za pomocą dwóch ujęć wody:

- brzegowo-przewodowego o wydajności $17280 \mathrm{~m}^{3} / \mathrm{d}$,

- podziemnego o wydajności $348 \mathrm{~m}^{3} / \mathrm{d}$.

Ze względu na niewielką wydajność ujęcia wody podziemnej analizie poddano jedynie SUW wody powierzchniowej. Pobrana woda jest uzdatniana na SUW w oparciu o system Actiflo i zespół dziewięciu filtrów pospiesznych. Uzdatniona woda po dodaniu chloru trafia do dwukomorowego zbiornika wody czystej o pojemności $5000 \mathrm{~m}^{3}$. Zbiornik ten $\mathrm{w}$ razie stwierdzenia nadmiernej mętności w wodzie surowej lub wystąpienia ewentualnej sytuacji kryzysowej stanowi zapas wody na około 22 godziny. Zbiorniki wody czystej zapewniają także niezbędny czas kontaktu wody z chlorem. Woda jest tłoczona do sieci za pomocą czterech pomp III $^{\mathrm{o}}$ sterowanych algorytmem stałego ciśnienia na tłoczeniu za pomocą przetwornicy częstotliwości. W czasie normalnej eksploatacji pracuje jedna pompa w systemie wymiennym co 24 godziny, pozostałe stanowią rezerwę. Nierównomierność dobową rozbioru wody wyrównuje zbiornik sieciowy dwukomorowy o pojemności $1800 \mathrm{~m}^{3}$. Układ sieci wodociągowej analizowanego miasta jest mieszany, pierścieniowo - rozgałęźny [9]. Analizowany SUW posiada system zabezpieczający konsumentów przed spożyciem zanieczyszczonej wody, składający się z kilku barier ochronnych [10].

W oparciu o schemat technologiczny SUW udostępniony przez przedsiębiorstwo wodociągowe, funkcjonujący od czasu modernizacji zakończonej w 2009 roku, sporządzono schemat niezawodnościowy analizowanego SUW (rysunek 1). 


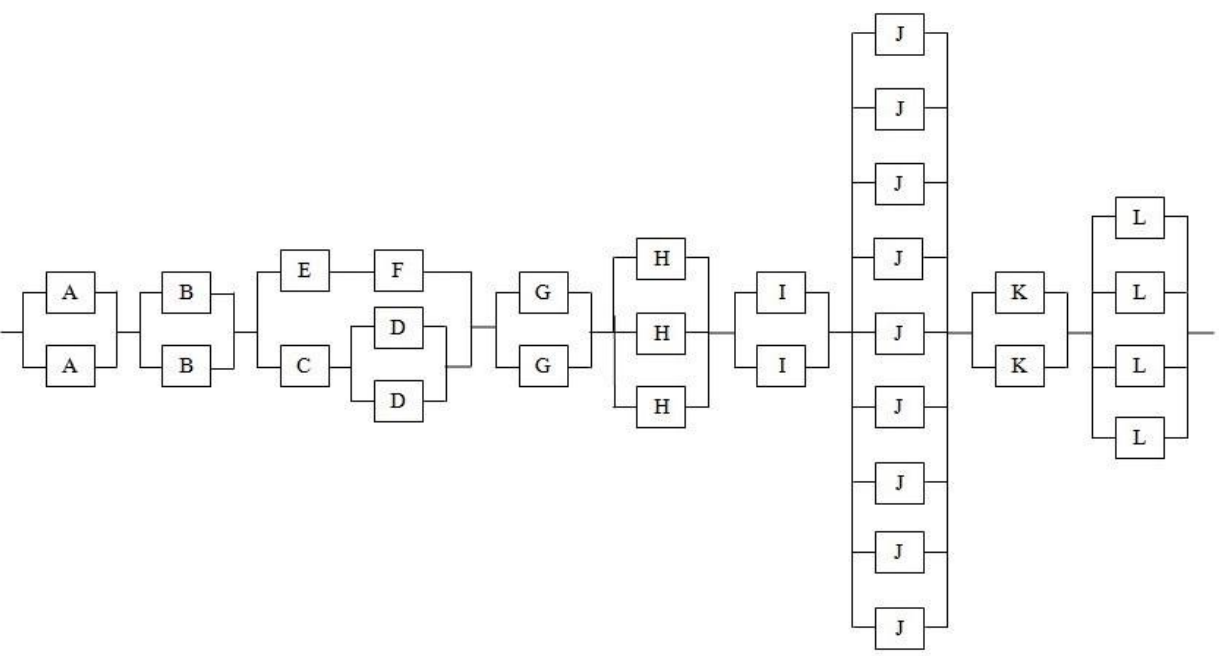

Rys.1. Schemat niezawodnościowy analizowanego SUW

Oznaczenia wykorzystane na rysunku 1: A - okno wlotowe, B - piaskownik, C studnia zbiorcza, D - pompa $\mathrm{I}^{0}, \mathrm{E}$ - studnia zbiorcza (rezerwa), $\mathrm{F}$ - pompa $\mathrm{I}^{\mathrm{0}}$ (rezerwa), G - osadnik wstępny, H - pompa II $^{\circ}$, I - blok Actiflo, J - filtr pospieszny, $\mathrm{K}$ - zbiornik wody czystej, $\mathrm{L}$ - pompa $\mathrm{III}^{\mathrm{o}}$.

\section{Wyniki}

Na podstawie danych eksploatacyjnych (dobowego raportu pracy SUW), oraz w oparciu o wzory (1) - (4) wyznaczono wskaźnik gotowości $\mathrm{K}_{\mathrm{g}}$ dla poszczególnych urządzeń wchodzących $\mathrm{w}$ skład SUW, co przedstawiono $\mathrm{w}$ tabeli 1. Przeanalizowano wszystkie odnotowane awarie na SUW w latach 2010 - 2015 (okres po modernizacji SUW).

Tabela 1. Wskaźnik gotowości dla obiektów wchodzacych w sktad analizowanego SUW

\begin{tabular}{|l|c|}
\hline \multicolumn{1}{|c|}{ Urządzenie } & Wskaźnik gotowości $\mathrm{K}_{\mathrm{g}}$ \\
\hline Okno wlotowe & $\mathrm{K}_{\mathrm{gA}}=0,9980$ \\
\hline Piaskownik & $\mathrm{K}_{\mathrm{gB}}=0,9991$ \\
\hline Studnia zbiorcza & $\mathrm{K}_{\mathrm{gC}}=0,9999$ \\
\hline Pompa I & $\mathrm{K}_{\mathrm{gD}}=0,9896$ \\
\hline Studnia zbiorcza (rezerwa) & $\mathrm{K}_{\mathrm{gE}}=0,9999$ \\
\hline Pompa I ${ }^{\mathrm{o}}$ (rezerwa) & $\mathrm{K}_{\mathrm{gF}}=0,9896$ \\
\hline Osadnik wstępny & $\mathrm{K}_{\mathrm{gG}}=0,9998$ \\
\hline Pompa II & $\mathrm{K}_{\mathrm{gH}}=0,9894$ \\
\hline Blok Actiflo & $\mathrm{K}_{\mathrm{gl}}=0,9731$ \\
\hline Filtr pospieszny & $\mathrm{K}_{\mathrm{gJ}}=0,9972$ \\
\hline Zbiornik wody czystej & $\mathrm{K}_{\mathrm{gK}}=0,9973$ \\
\hline Pompa III & $\mathrm{K}_{\mathrm{gL}}=0,9842$ \\
\hline
\end{tabular}


$\mathrm{Na}$ podstawie opracowanego schematu niezawodnościowego, przedstawiającego wzajemne zależności pomiędzy elementami (rysunek 1), oraz w oparciu o wzory (6) - (8) wyznaczono wskaźnik gotowości $\mathrm{K}_{\mathrm{g}}$ dla poszczególnych struktur oraz dla całego SUW:

$$
\begin{array}{ll}
K_{g I}=1-\left(1-K_{g A}\right)^{2}=0,9999 & K_{g V I}=1-\left(1-K_{g I V}\right)\left(1-K_{g V}\right)=0,9999 \\
K_{g I I}=1-\left(1-K_{g B}\right)^{2}=0,9999 & K_{g V I I}=1-\left(1-K_{g G}\right)^{2}=0,9999 \\
K_{g I I I}=1-\left(1-K_{g D}\right)^{2}=0,9999 & K_{g V I I I}=1-\left(1-K_{g H}\right)^{3}=0,9999 \\
K_{g I V}=K_{g C} \cdot K_{g I I I}=0,9998 & K_{g I X}=1-\left(1-K_{g I}\right)^{2}=0,9993 \\
K_{g V}=K_{g E} \cdot K_{g F}=0,9895 &
\end{array}
$$

$$
\begin{aligned}
& K_{g X}=\left(\begin{array}{l}
9 \\
0
\end{array}\right) \cdot K_{g J}{ }^{9} \cdot K_{p J}{ }^{0}+\left(\begin{array}{l}
9 \\
1
\end{array}\right) \cdot K_{g J}{ }^{9-1} \cdot K_{p J}^{1}+\left(\begin{array}{l}
9 \\
2
\end{array}\right) \cdot K_{g J}{ }^{9-2} \cdot K_{p J}^{2}=0,9999 \\
& K_{g X I}=1-\left(1-K_{g K}\right)^{2}=0,9999 \\
& K_{g X I I}=1-\left(1-K_{g L}\right)^{4}=0,9999 \\
& K_{g S U W}=K_{g I} \cdot K_{g I I} \cdot K_{g V I} \cdot K_{g V I I} \cdot K_{g V I I I} \cdot K_{g I X} \cdot K_{g X} \cdot K_{g X I} \cdot K_{g X I I}=0,9985
\end{aligned}
$$

Obliczenia przeprowadzono dla rzeczywistego zapotrzebowania na wodę, nie dla całkowitej zdolności produkcyjnej SUW, która jest o wiele większa niż zapotrzebowanie na wodę dla miasta. Otrzymaną wartość wskaźnika gotowości $\mathrm{K}_{\mathrm{gSuw}}$ porównano $\mathrm{z}$ wartościami kryterialnymi przedstawionymi $\mathrm{w}$ pracy [18]. System zbiorowego zaopatrzenia $\mathrm{w}$ wodę analizowanego miasta zaopatruje w wodę około 34500 mieszkańców oraz pokrywa w 100\% zapotrzebowanie na wodę dla miasta. Wartość wymaganego wskaźnika gotowości dla SZZW poddanego analizie wynosi $\mathrm{K}_{\mathrm{gsZZW}}=0,9150137$. Ponieważ SZZW składa się z dwóch podsystemów, wartość wskaźnika gotowości dla każdego z nich wynosi $K_{\text {gwym }}=\sqrt{0,9150137}=0,9566$. Porównując otrzymany wskaźnik gotowości $\mathrm{z}$ wartością wymaganą stwierdzono, że $\mathrm{K}_{\mathrm{gsuw}}>\mathrm{K}_{\mathrm{gwym}}$.

\section{Wnioski}

Analizę niezawodności SUW analizowanego miasta przeprowadzono na podstawie udostępnionych przez przedsiębiorstwo wodociągowe danych eksploatacyjnych. Stacja uzdatniania wody analizowanego miasta spełnia wymagania niezawodnościowe stawiane tego typu obiektom. Ze względu na znaczące rezerwowanie obiektów wchodzących w skład SUW prawdopodobieństwo niezdatności SUW jest znikome.

Szczególną uwagę zwraca wysoki poziom rezerwowania wody $\mathrm{w}$ zbiornikach wody czystej $\mathrm{V}=5000 \mathrm{~m}^{3}$ oraz zbiornikach sieciowych $\mathrm{V}=1800 \mathrm{~m}^{3}$. W przypadku niezdatności SUW, zbiorniki te mogą stanowić źródło wody dla miasta, co dodatkowo podnosi poziom bezpieczeństwa konsumentów wody. 
Analysis and assessment of water treatment plant reliability

Analiza i ocena niezawodności stacji uzdatniania wody

Stacja uzdatniania wody analizowanego miasta posiada kompleksowy system ochrony: strefy ochronne ujęcia wody, wysokie ogrodzenie obiektu SUW, automatyczna brama wjazdowa obsługiwana przez pracowników SUW, pełny monitoring obiektów SUW, automatyzacja procesów uzdatniania, stały nadzór pracowników nad pracą urządzeń (system SCADA), równoległy automatyczny oraz ręczny monitoring jakości wody jak również plan reagowania kryzysowego w przypadku wystąpienia sytuacji kryzysowej. Zabezpieczenie SUW analizowanego miasta spełnia zatem wymagania stawiane infrastrukturze krytycznej.

\section{Literatura}

[1] Boryczko K., Tchórzewska-Cieślak B.: Analysis of risk of failure in water main pipe network and of developing poor quality water. Environment Protection Engineering, 40(4)/2014, s. 77-92.

[2] Budziło B., Polok-Kowalska A.: Dwuparametryczna ocena niezawodności funkcjonowania podsystemu dostawy wody dla miasta Limanowa. Czasopismo Techniczne. Środowisko. R. 104, z. 2-Ś/2007, s. 29-38.

[3] Hrudey S.E., Hrudey E.J., Pollard S.J.: Risk management for assuring safe drinking water. Environment International, 32(8)/ 2006, s. 948-957.

[4] Iacob, I.E., Apostolou, A.: A quantitative risk analysis framework for bow-tie models. Proceedings of the 2015 7th International Conference on Electronics, Computers and Artificial Intelligence, ECAI 2015, 7301176, pp. Y43-Y46.

[5] Kwietniewski M., Roman M., Kłoss-Trębaczkiewicz H.: Niezawodność wodociągów i kanalizacji. Arkady, Warszawa, 1993.

[6] Rak J.: Niezawodność systemu uzdatniania wód powierzchniowych. Zeszyty Naukowe Politechniki Rzeszowskiej, nr 20, Rzeszów, 1993.

[7] Rozporządzenie Ministra Zdrowia z dnia 13 listopada 2015 r. w sprawie jakości wody przeznaczonej do spożycia przez ludzi (Dz.U. 2015 poz. 1989).

[8] Studziński A., Pietrucha-Urbanik K.: Preventive maintenance and reliability of water supply system elements. Czasopismo Inżynierii Lądowej, Środowiska i Architektury, JCEEA, t. XXXII, z. 62 (3/I/15), lipiec-wrzesień 2015, s. 429436. (DOI: 10.7862/rb.2015.126).

[9] Szpak D., Tchórzewska - Cieślak B.: Analiza awaryjności sieci wodociągowej $\mathrm{w}$ aspekcie bezpieczeństwa funkcjonowania infrastruktury krytycznej. CHEMIK, 68(10)/2014, s. 862-867.

[10] Szpak D., Tchórzewska - Cieślak B.: Analiza i ocena zabezpieczenia systemów zbiorowego zaopatrzenia $\mathrm{w}$ wodę przed incydentalnym skażeniem. Journal of KONBiN 2(34)/2015, s. 49 - 58 (DOI 10.1515/jok-2015-023).

[11] Szymik-Gralewska J., Zimoch I.: Zasady optymalizacji niezawodności eksploatacji stacji uzdatniania wody, Monografia - XXIII Międzynarodowa Konferencja Naukowo - Techniczna „Zaopatrzenie w wodę, jakość i ochrona wód- WODA 2014”, s. 157-178. 
[12] Tchórzewska-Cieślak B.: Method of assessing of risk of failure in water supply system. European safety and reliability conference 2007 (ESREL 2007), Risk, reliability and societal safety, Taylor \& Francis, 2, 1535-1539.

[13] Tchórzewska-Cieślak B.: Niezawodność i bezpieczeństwo systemów komunalnych na przykładzie systemu zaopatrzenia w wodę. Oficyna Wydawnicza Politechniki Rzeszowskiej, Rzeszów, 2008.

[14] Tchórzewska-Cieślak B., Boryczko K., Piegdoń I.: Possibilistic risk analysis of failure in water supply network. Safety and Reliability: Methodology and Applications - Proceedings of the European Safety and Reliability Conference, ESREL 2014, pp. 1473-1480.

[15] Tchórzewska-Cieślak B., Pietrucha-Urbanik K., Szpak D.: Safety problems of small water supply systems. Journal of KONBiN 1(37)/2016, pp. 51-72 (DOI 10.1515/jok-2016-0003).

[16] Ustawa $\mathrm{z}$ dnia 7 czerwca 2001 r. o zbiorowym zaopatrzeniu w wodę i zbiorowym odprowadzaniu ścieków (Dz.U. 2001 nr 72 poz. 747) z późniejszymi zmianami.

[17] Ustawa z dnia 26 kwietnia 2007 r. o zarządzaniu kryzysowym (Dz.U. 2007 $\mathrm{Nr} 89$ poz. 590) z późniejszymi zmianami.

[18] Wieczysty A.: Metody oceny i podnoszenia niezawodności działania komunalnych systemów zaopatrzenia w wodę. Monografie Komitetu Inżynierii Środowiska Polskiej Akademii Nauk, vol. 2., Komitet Inżynierii Środowiska PAN, Kraków, 2001.

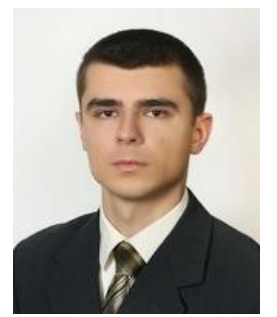

Mgr inz. Dawid Szpak pracuje na stanowisku asystenta w Zaktadzie Zaopatrzenia w Wodę i Odprowadzania Ścieków Politechniki Rzeszowskiej. Zainteresowania naukowe: niezawodność $i$ bezpieczeństwo systemów zaopatrzenia $w$ wodę, $z$ darzenia incydentalne $w$ systemach zaopatrzenia $w$ wodę (udziat $50 \%)$.

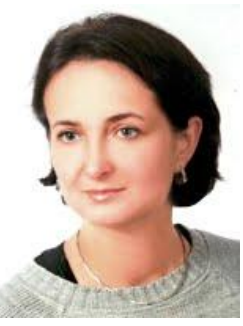

Dr hab. inż. Barbara Tchórzewska-Cieślak, prof. PRz pracuje na stanowisku profesora nadzwyczajnego $w$ Zaktadzie Zaopatrzenia $w$ Wodę i Odprowadzania Ścieków Politechniki Rzeszowskiej. Zainteresowania naukowe: systemy zaopatrzenia $w$ wodę, niezawodność i bezpieczeństwo systemów inżynierskich, niekonwencjonalne metody analizy i oceny ryzyka (udziat 50\%). 
Analysis and assessment of water treatment plant reliability Analiza i ocena niezawodności stacji uzdatniania wody 